\title{
Floyd Gray, La renaissance des mots. De Jean Lemaire de Belges à Agrippa d'Aubigné
}

\section{Filippo Fassina}

\section{(2) OpenEdition}

1 Journals

\section{Edizione digitale}

URL: http://journals.openedition.org/studifrancesi/8224

DOI: $10.4000 /$ studifrancesi.8224

ISSN: 2421-5856

\section{Editore}

Rosenberg \& Sellier

\section{Edizione cartacea}

Data di pubblicazione: 1 mai 2009

Paginazione: 158-159

ISSN: 0039-2944

\section{Notizia bibliografica digitale}

Filippo Fassina, «Floyd Gray, La renaissance des mots. De Jean Lemaire de Belges à Agrippa d'Aubigné», Studi Francesi [Online], 157 (LIII | I) | 2009, online dal 30 novembre 2015, consultato il 09 janvier 2021. URL: http://journals.openedition.org/studifrancesi/8224; DOI: https://doi.org/10.4000/studifrancesi. 8224

Questo documento è stato generato automaticamente il 9 janvier 2021.

\section{(c)}

Studi Francesi è distribuita con Licenza Creative Commons Attribuzione - Non commerciale - Non opere derivate 4.0 Internazionale. 


\section{Floyd Gray, La renaissance des mots. De Jean Lemaire de Belges à Agrippa d'Aubigné}

Filippo Fassina

\section{NOTIZIA}

FLOYD GRAY, La renaissance des mots. De Jean Lemaire de Belges à Agrippa d'Aubigné, Paris, Champion, 2008 («Études et Essais sur la Renaissance», LXXVIII), pp. 433.

1 Il presente studio intende offrire un panorama storico dell'evoluzione della lingua francese volgare a partire dalla sua emancipazione rispetto alla lingua latina. Parallelamente, vengono presentati alcuni testi teorici relativi allo statuto e all'autonomia della lingua nazionale e viene dato ampio spazio alla descrizione degli strumenti di trasmissione della cultura, soprattutto per quanto riguarda la stampa e i suoi metodi di diffusione. A partire da queste premesse, la prima parte del lavoro è dedicata alla nascita della stampa, delle edizioni critiche e all'imporsi della lingua francese volgare come lingua letteraria. Successivamente (seconda, terza e quarta parte), l'A. offre come esempio alcuni testi fondamentali nello sviluppo della lingua: l'opera di Rabelais, alcuni commentari ai testi di Du Bellay e gli Essais di Montaigne. Nell'ultima parte, viene introdotto il tema della scrittura legata all'erotismo, riguardo alla quale vengono analizzate le opere di Jean Lemaire de Belges, Jeanne Flore e d'Aubigné. Da notare, in conclusione, un ricco apparato bibliografico. 